【論【文】

\title{
密度成層大気中の物体上流側のよどみ域について \\ THE FLOW STAGNANT ZONE UPSTREAM OF AN OBSTACLE IN DENSITY STRATIFIED FLOW IN ATMOSPHERE
}

\author{
北 林 興 二* \\ By Koji KITABAYASHI
}

\section{1. まえがき}

地形が複雑で入り組んだ海岸線をもつわが国では, 大 気の流れに及ぼす地形の 影響を研究することは 環境問 題, 特に, 大気污染問題に関連して重要である. 地形と 熱との相互作用で発生する風のうち, 大気污染問題に特 に関連の深いものは, 海陸風, 山谷風などである. 海陸 風は海と陸の比熱の相違により発生するものであるが， 日中の海風時に拡散能が大となり, 大発生源の多い工場 地域での大気環境問題に関連が深い. 一方, 中小排出源 や自動車排ガスなど地表面近くで排出される污染質につ いては,これとは逆に, 冬期の夜間など拡散効果の悪化 する安定成層条件下で高濃度となることが知られてい る.

安定成層条件での大気現象として一般的なものに“山 越え気流”がある. 山越え気流は, 山を越えた気流が密 度成層の存在のため波動を生ずるものである. 密度成層 効果が慣性効果より大きい場合, 下層の気塊は十分な慣 性力をもたないため, 山を越えられず, 山の上流側に気 塊のよどみが発生することがある.これが “よどみ域” であり, Long ${ }^{1), 2)} や \mathrm{Kao}^{3)}$ により理論的検討が行われ た.また, $\mathrm{Kao}^{4)}$, 日野・大西 ${ }^{5), 6)}$ は, Point Sink への 流れの場でのよどみ域について報告している.

$\mathrm{Kao}^{3)}$ は, 高さH のチャンネル内密度成層流中の床 面に物体が存在する場合を考え, チャンネル高さを基準 長さとしたフルード数 $\left(F_{r}=U /\left(g H^{2}(d \rho / d z) / \rho_{0}\right)^{1 / 2}\right)$ が $1 / \pi$ 以下でよどみ域が形成されると結論した. 彼は物体 の高さとよどみ域の関係については検討しておらず，よ どみ域の形成されるフルード数は物体の高さに無関係と

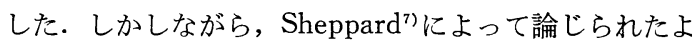
うに, 気塊が物体を越えるに必要な最小限の慣性力は物 体の高さに無関係ではないと考えられる．この報告では

\footnotetext{
* 正会員 工業技術院公害資源研究所 主任研究官
}

安定層高さに比較して物体が小さく,また, 上部の境界 の存在が無視し得るものとして, 大気の流れを $\mathrm{Yih}^{8)} の$ 導いた非粘性, 定常, 密度成層チャンネル内流れにより 近似する。また，障害物あるいは山岳を単純化し，薄板 Barrier により置き換えたモデルにより，よどみ域発生 とフルード数の関係, フルード数による流れの変化など について論じた。また，これらの結果を風洞実験により 検証した.

\section{2. 流れの基本式}

安定成層状態にある大気の流れは山岳気流程度のスケ ールでは, 地表面のごく近くを除き, 非粘性, 非拡散性, 非圧縮性流れとして取り扱うことができる、Yih は, よく知られた Yih の変換を導入して基礎方程式を簡単 化し, 上流無限遠で流速が一様で密度勾配が一定のチャ ンネル内流れは流関数に関する線形方程式で表されるこ とを示した.

ここで基本方程式の導出過程を簡単に紹介する.

非粘性, 非拡散, 非圧縮, 2 次元定常流は流れの場を 図一1 で表し, 一様流方向の流速成分を $u$, 鉛直方向の 流速成分をwとすると以下のように書ける.

$$
\begin{aligned}
& \rho\left(u \frac{\partial u}{\partial x}+w \frac{\partial u}{\partial z}\right)=-\frac{\partial P}{\partial x} \\
& \rho\left(u \frac{\partial w}{\partial x}+w \frac{\partial w}{\partial z}\right)=-\frac{\partial P}{\partial z}-g \rho \\
& \frac{\partial}{\partial x}(\rho u)+\frac{\partial}{\partial z}(\rho w)=0
\end{aligned}
$$

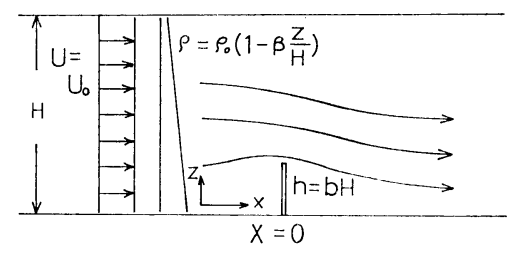

図一1＼cjkstart薄板 Barrier を越える流れの坐標系 


$$
u \frac{\partial \rho}{\partial x}+w \frac{\partial \rho}{\partial z}=0
$$

式 (1)，(2) は運動方程式を，式 (3) は連続の条件を, また，式（4）渄圧縮，非拡散流れの条件を表す.

ここで, 従属変数に対する Yih の変換, および流関 数 $\psi^{\prime}$ を次のように導入する.

$$
\begin{aligned}
& \left(u^{\prime}, w^{\prime}\right)=\sqrt{\frac{\rho}{\rho_{0}}}(u, w) \\
& u^{\prime}=-\frac{\partial \psi^{\prime}}{\partial z}, w^{\prime}=\frac{\partial \psi^{\prime}}{\partial x}
\end{aligned}
$$

ここで， $\rho_{0}$ は流体の代表密度．たとえば，上流無限遠 での断面平均密度である。

基本式（1）～（4）に変換式 (5)，(6) を適用し，さらに 流体要素のトータル・エネルギー，つまり，Bernoulli's Constant が流線に沿って保存されることを考慮すると， 流れの方程式は結局, 流関数 $\psi^{\prime}$ に関する線形方程式,

$$
\nabla^{2} \Psi+F_{r \pi}{ }^{-2} \Psi=-F_{r \pi}{ }^{-2} \eta
$$

に書き換えられる.ここで， $\nabla^{2}$ はよく知られたラプラ ス演算子であり, $\Psi, \xi, \eta, F_{r \pi}$ は次のよらな無次元量で ある。

$$
\begin{aligned}
& \nabla^{2}=\frac{\partial^{2}}{\partial \xi^{2}}+\frac{\partial^{2}}{\partial \eta^{2}}, \quad \xi=\frac{\pi x}{H}, \eta=\frac{\pi z}{H} \\
& \Psi=\frac{\pi \psi^{\prime}}{U H}, \quad F_{r \pi}=\frac{U \pi}{N H}, N^{2}=-\frac{g}{\rho_{0}}\left(\frac{\partial \rho}{\partial z}\right)_{x=-\infty}
\end{aligned}
$$

$F_{r \pi}$ は慣性項 と 浮力項の比を表す内部フルード数であ り，また，Nは流体層の個有周波数で Brunt-Väisälä 周 波数とよばれる.

\section{3. 薄板 Barrier を越える密度成層流の解}

流れの場は, 図一1 に示される 2 次元チャンネル内流 れであり, その底面に高さ $h(=b H)$ の薄板 Barrier が 垂直に立っているものとする，流れは上流無限遠，つま り, $X=-\infty$ で一様流速, 一定密度勾配にあるものとす る.

流れの基本式は式 (7) で表され，解の満たすべき境界 条件は基本的には次の 4 条件である。

(1) $\Psi=-\eta, \xi=-\infty$

(2) $\Psi=0, \quad \eta=0, \quad \xi \neq 0$

(3) $\Psi=0, \quad 0 \leq \eta<b \pi, \quad \xi=0$

(4) $\Psi=-\pi, \eta=\pi$

このモデルではさらに，非成層流れ（ $\left.F_{r \pi}=\infty\right)$ にお ける Barrier 上部 $(\xi=0, b \pi \leq \eta \leq \pi)$ での 流関数 $\Psi_{\xi=0}$ をポテンシャル流の解を近似するように定め，ま た， $\Psi_{\xi=0}$ の密度成層条件による変化は，流線に沿う Bernoulli's Constant の保存則から求めた. 境界条件(1) は、いわゆる “Long's Hypothesis”とよばれるもので めり，上流無限遠まで擋乱が及ばず，そこで流速が一様
であることを仮定するものである．密度成層流体中では 擋乱は波動として伝播してゆくため，この仮定は有効で ないとの説もあり, 最近, McIntyre ${ }^{9)}$ Baines $^{10)}, W e i^{11)}$ ほかなどにより理論的, 実験的な検討もなされている.

McIntyre は理論的な検討から，滑らかな物体につい ては上流側への影響が生じないことを述べている。また Wei らは水槽実験から，物体上流側での 流速変化がフ ルード数 $0.13\left(F_{r \pi}\right.$ で 0.41$)$ でも $10 \%$ 程度であるこ とを示しており， $F_{r \pi}$ が 0.5 以上では Long の仮説も 有効であるといえよう。この報告では，浮力効果が慣性 効果に比較して極端に強くはない $F_{r \approx}$ が 0.5 程度まで の流れを扱らこととする。

\section{(1) $\boldsymbol{F}_{r_{\pi}}>1$ の場合の理論解}

a) Barrier 上流側の解

基本方程式 (7) と境界条件を満足する解は，一様流を 表す項と Barrier による流れの変化を表す項 $\Psi_{u}$ の和と して次式のように表される.

$$
\Psi=-\eta+\Psi_{u}
$$

右辺第 2 項 $\Psi_{u}$ を日野・大西占,6) にならい, $F_{r \pi}{ }^{-2}$ につ いての摂動解として次式のように表す.

$$
\Psi_{u}=\psi_{0}+\delta \psi_{1}+\delta^{2} \psi_{2}+\cdots,
$$

ここで, $\delta$ は摂動パラメーターであり,$F_{r_{\pi}}^{-2}$ に等し

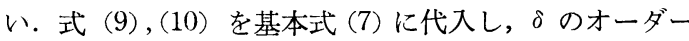
ごとに整理することにより， $\psi_{0}, \psi_{1}, \cdots$ に対する次のよ うな方程式群を得る。

$$
\begin{aligned}
& O\left(\delta^{0}\right): \nabla^{2} \psi_{0}=0 \cdots \cdots \cdots \cdots \cdots \cdots \cdots \cdots \cdots \cdots \cdots \cdots \cdots \cdots(11 \cdot \mathrm{a}) \\
& O\left(\delta^{m}\right): \nabla^{2} \psi_{m}=-\psi_{m-1}, m \geq 1 \cdots \cdots \cdots \cdots(11 \cdot \mathrm{b})
\end{aligned}
$$

これらの方程式を $\psi_{0}, \psi_{1}, \psi_{2}, \cdots$ の順に解くことによ り, 流関数 $\Psi_{u}$ が定まる.

(1) 第 1 次摂動解 $\psi_{0}$ :

第 1 次捸動解 $\psi_{0}$ の方程式は式 (11・a) で示されるよ らに，ラブラスの方程式であり，式 (9) の右辺第 1 項と ともに Barrier を越えるポテンシャル流の解を表す. たがって，将に関する境界条件は次のように書ける.

$$
\begin{array}{ll}
\psi_{0}=0, & \xi=-\infty \\
\psi_{0}=0, & \eta=\pi \\
\psi_{0}=0, & \eta=0, \xi \neq 0 \\
\psi_{0}-\eta=0, & 0 \leq \eta \leq b \pi, \xi=0
\end{array}
$$

この境界条件を満足する式 (11・a) の解は,

$$
\psi_{0}=\sum_{n=1}^{\infty} a_{n} e^{n \xi} \sin n \eta
$$

で表される. 係数 $a_{n}$ は $\psi_{0}$ の $\xi=0$ での境界条件から 定められる.ここで, 係数 $a_{n}$ を定めるため, 上の境界 条件を満足する関数 $g_{0}(\eta)$ を次のように導入する.

$$
\begin{array}{ll}
g_{0}(\eta)=\eta, & 0 \leq \eta<b \pi \cdots \cdots \cdots(13 \cdot \mathbf{a}) \\
g_{0}(\eta)=\frac{b \pi}{(\pi-b \pi)^{m}}(\pi-\eta)^{m}, b \pi \leq \eta=\pi
\end{array}
$$


$(13 \cdot b)$

前述のよらに, 関数 $\left(-\eta+\psi_{0}\right)$ は Barrier を越えるポ テンシャル流の解である.ここでは, この関数がポテン シャル流をよく近似するよう $m$ を定める. $g_{0}(\eta)$ は式 (12) で $\xi=0$ としたものと等しくなければならない. 係 数 $a_{n}$ は $g_{0}(\eta)$ をフーリエ級数に 展開することにより 次のように定まる.

$$
\begin{aligned}
a_{n}= & \frac{2 \sin n \pi b}{n^{2}}-2 \pi b(m !) \cos n \pi b \\
& \left\{\frac{1}{n^{3}(m-2) !(\pi-b \pi)}+\frac{1}{n^{5}(m-4) !(\pi-b \pi)^{4}}+\cdots\right\} \\
& +2 \pi h(m !) \sin n \pi b\left\{\frac{1}{n^{2}(m-1) !(\pi-b \pi)}\right. \\
& \left.+\frac{1}{n^{4}(m-3) !(\pi-b \pi)^{3}}+\cdots\right\} \cdots \cdots \cdots \cdots \cdots \cdots(14)
\end{aligned}
$$

これにより求められた解がどの程度ポテンシャル流の解 を表すかを確かめるため, 電子計算機による数值解と比 較したものが図一2である. 図は Barrier 上流側での流 関数分布を比較したものであるが両者の一致はきわめて よいといえる. なお, 解析解では $m$ を 3 としている.

(2) 第 2 次摂動解 $\psi_{1}$ :

基本解 $(-\eta)$ と第 1 次摂動解により流関数 $\Psi_{u}$ の満た すべき境界条件はすべて満たされている．したがって， 第 2 次摂動解 $\psi_{1}$ の満たすべき境界条件は次の 2 つであ る.

$$
\begin{aligned}
& \psi_{1}=0, \eta=0 \text { および } \pi \\
& \psi_{1}=0, \xi=-\infty
\end{aligned}
$$

この条件を满たす式 $(11 \cdot \mathrm{b})$ の解は，

$$
\psi_{1}=\sum_{n=1}^{\infty}\left(A_{n}+B_{n} \xi\right) e^{n \xi} \sin n \eta
$$

上書ける. 係数 $B_{n}$ は式 (11·b) に式 (12), (15) を代入 することにより，次のように定まる.

$$
B_{n}=-\frac{a_{n}}{2 n}
$$

係数 $A_{n}$ はこのままでは定まらないが， $\psi_{1}$ についての $\xi=0$ での条件から決定される. これについては後述す る.

\section{(3) 第 3 次摂動解 $\psi_{2}$ :}

第 3 次摂動解も $\psi_{1}$ とまったく同様にして次のように 求められる.

$$
\psi_{2}=\sum_{n=1}^{\infty}\left(C_{n}+D_{n} \xi+E_{n} \xi^{2}\right) e^{n \Sigma} \sin n \eta
$$

ここで，係数 $D_{n}, E_{n}$ は次式で与えられる.

$$
\begin{aligned}
D_{n} & =-\frac{a_{n}}{8 n^{3}}-\frac{A_{n}}{2 n} \\
E_{n} & =\frac{a_{n}}{8 n^{2}} \ldots \ldots \ldots \ldots \ldots
\end{aligned}
$$

$C_{n}$ も $A_{n}$ と同様， $\psi_{2}$ の $\xi=0$ での条件から定まる ものであり, これについても後述する.

式 (12)，(15)，(17) より $\xi=0^{-}\left(\lim _{\xi \rightarrow 0} 0-\xi\right)$ での流関数 $\Psi_{u, 0^{-}}$は

$$
\Psi_{u, 0^{-}}=\sum_{n=1}^{\infty}\left(a_{n}+\delta A_{n}+\delta^{2} C_{n}\right) \sin n \eta
$$

となり, $A_{n}, C_{n}$ は密度成層の変化に伴う $\xi=0^{-}$での 流関数分布の変化を表す係数である.

b) Barrier 下流側の解 $\Psi_{d}$

密度成層流中の Barrier 下流側ではよく知られた山越 え気流が生じ, 上流側の流れとは大変異なったものとな る. ここでは, 非定常流の $t=\infty$ での極限の解として Trustrum ${ }^{12)}$ によって示されたものを形式的に採用する. $\Psi_{d}$ は次のように書ける。

$$
\begin{aligned}
\Psi_{d} & =-\eta+\sum_{n=1}^{K}\left\{G_{n} \sin \lambda_{n} \xi+H_{n} \cos \lambda_{n} \xi\right\} \sin n \eta \\
& +\sum_{n=K+1}^{\infty}\left\{J_{n} e^{-\lambda_{n} \hat{\kappa}}+K_{n}\right\} \sin n \eta \ldots \ldots \ldots \ldots(20)
\end{aligned}
$$

ここで, 係数 $\lambda_{n}$ は

$$
\lambda_{n}=\left\{\left|\delta-n^{2}\right|\right\}^{1 / 2}
$$

で与えられ，Kは立た $\delta-n^{2}$ が負となら

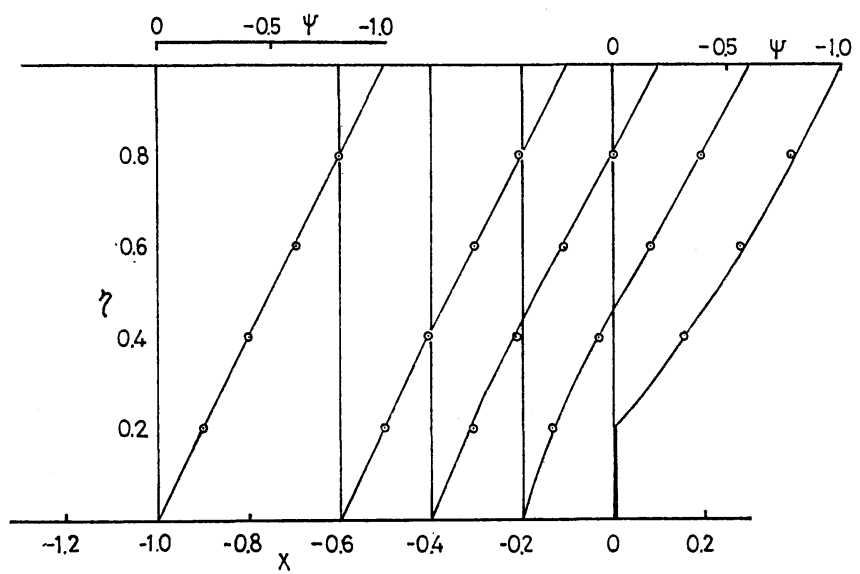

図一2 流関数 ( ○は数值計算の)解, $m=3$ ( ) 場们) ない最大の $n$ の值である. 式 (20)の係数 $\left(G_{n}, H_{n}, J_{n}, K_{n}\right)$ は, 上流側の解 $\Psi_{u}$ 之 下流側の解 $\Psi_{d}$ を $\xi=0$ で滑らかに接続す るよう定める. 係数を定める条件は $\xi=0$ における $\Psi_{u}, \Psi_{d}$ およびその微係数の連続 性であり, 次の 3 条件となる.

(1) $\Psi_{u, \xi \leqslant 0}=\Psi_{d, \xi=0^{+}}$

(2) $\left(\frac{\partial \Psi_{u}}{\partial \eta}\right)_{\xi=0^{-}}=\left(\frac{\partial \Psi_{d}}{\partial \eta}\right)_{\hat{\xi}=0^{+}}$

(3) $\left(\frac{\partial \Psi_{u}}{\partial \xi}\right)_{\xi=0^{-}}=\left(\frac{\partial \Psi_{d}}{\partial \xi}\right)_{\xi=0^{+}}$

ここで，（） $\xi_{\xi=0^{+}}, （ ）_{\xi=0^{-}}$はそれぞれ， （について正の方向あるいは負の方向から 0 に近づいた極限での量を表す。これらの 条件から，係数 $\left(i_{n}, I I_{n}, J_{n}, K_{n}\right.$ (小次U) 
ように定められる.

$$
\begin{aligned}
G_{n}= & \frac{1}{\lambda_{n}}\left\{n a_{n}+\delta\left(n A_{n}-\frac{a_{n}}{2 n}\right)\right. \\
& \left.+\delta^{2}\left(n C_{n}-\frac{a_{n}}{8 n^{3}}-\frac{A_{n}}{2 n}\right)\right\} \cdots \cdots \cdots \cdots(22) \\
H_{n}= & a_{n}+\delta A_{n}+\delta^{2} C_{n} \cdots \cdots \cdots \cdots \cdots \cdots \cdots \cdots \cdots(23) \\
J_{n}= & -\frac{1}{\lambda_{n}}\left\{n a_{n}+\delta\left(n A_{n}-\frac{a_{n}}{2 n}\right)\right. \\
& \left.+\delta^{2}\left(n C_{n}-\frac{a_{n}}{8 n^{3}}-\frac{A_{n}}{2 n}\right)\right\} \cdots \cdots \cdots \cdots \cdots(24) \\
K_{n}= & \left\{a_{n}+\delta A_{n}+\delta^{2} C_{n}\right\}+\frac{1}{\lambda_{n}}\left\{n a_{n}+\delta\left(n A_{n}-\frac{a_{n}}{2 n}\right)\right. \\
& \left.+\delta^{2}\left(n C_{n}-\frac{a_{n}}{8 n^{3}}-\frac{A_{n}}{2 n}\right)\right\} \cdots \cdots \cdots \cdots \cdots(25)
\end{aligned}
$$

c) 係数 $A_{n}, C_{n}$ の決定

係数 $A_{n}, C_{n}$ はそれぞれ $\xi=0$ での $\psi_{1}$ 扎よび $\psi_{2}$ の 分布から定まる.ここでは Bernoulli の定理を適用し, 流体のトータル・エネルギーが流線に沿って保存される ことから $A_{n}, C_{n}$ を求める. 流体要素のもつトータル エネルギー $H_{e}$ は $p$ を圧力, $q$ を流速, $\eta$ を流体要素 の鉛直座標として次式で表される.

$$
H_{e}=p+\frac{1}{2} \rho q^{2}+\rho g \frac{H}{\pi} \eta
$$

$H_{e}$ を $\xi=0$ と $\xi=-\infty$ について求め, 同じ流線につ いて等しく置くことにより $A_{n}, C_{n}$ が定まる.

\section{- $\xi=0$ での静圧項 $p_{0^{-}}$:}

$p$ は上流無限遠で $\eta=\pi$ での静圧を $p_{\infty}$ とし, さらに Barrier の存在による断面の縮少に伴う静圧の変化を $f(U)$ とすると次式で表される.

$$
\begin{aligned}
& p_{0}-=p_{\infty}+\int_{\eta}^{\pi} \rho g \frac{H}{\pi} d \eta+f(U) \\
& =p_{\infty}-\frac{1}{2} \rho_{0} U_{\infty}{ }^{2}\left\{\sum_{n=1}^{\infty} n a_{n} \cos n \eta\right\}^{2} \\
& +\rho_{0}\left[g \frac{H}{\pi}(\pi-\eta)-\frac{1}{2} g \frac{H}{\pi} \beta(\pi-\eta)^{2}\right. \\
& -g \frac{H}{\pi} \beta \sum_{n=1}^{\infty} \frac{1}{n}\left\{\left(a_{n}+\delta A_{n}+\delta^{2} C_{n}\right)\right. \\
& \left.\left.\left((-1)^{n}-\cos n \eta\right)\right\}\right]
\end{aligned}
$$

ここで, 右辺第 2 項は流路断面の変化に伴う静圧変化を 表すものであり, 簡単のため高さ方向に一様であるとし た.

\section{- $\xi=0$ での慣性項 $1 / 2 \rho_{0} q^{2}$ :}

$\xi=0$ での慣性項は流関数の $\xi=0$ (゙のの微係数をとり, 鉛直成分を無視すると次のように書ける.

$$
\begin{aligned}
& \left(\frac{1}{2} \rho_{0} q^{2}\right)_{\xi=0^{-}}=\frac{1}{2} \rho_{0} U_{\infty^{2}}\left[\left\{-1+\sum_{n=1}^{\infty} n a_{n} \cos n \eta\right\}^{2}\right. \\
& +2\left\{-1 \div \sum_{n=1}^{\infty} n a_{n} \cos n \eta\right\}\left\{\sum_{n=1}^{\infty}\left(\delta A_{n}+\delta^{2} C_{n}\right) \cos n \eta\right\} \\
& +\left\{\sum_{n=1}^{\infty}\left(i \Lambda_{n}+\delta^{2}\left(_{n}^{\prime}\right) \cos n \eta\right\}^{2}\right.
\end{aligned}
$$

$$
\begin{aligned}
& +\delta^{2}\left\{\sum_{n=1}^{\infty}\left(n A_{n}+B_{n}\right) \sin n \eta\right\}^{2}+\delta^{3}\left\{\sum_{n=1}^{\infty} n A_{n} \sin n \eta\right\} \\
& \cdot\left\{\sum_{n=1}^{\infty} D_{n} \sin n \eta\right\}+\delta^{2}\left\{\sum_{n=1}^{\infty} n C_{n} \sin n \eta\right\} \\
& \left.\cdot\left\{\sum_{n=1}^{\infty} C_{n} \sin n \eta\right\}\right] \ldots \ldots \ldots \ldots \ldots \ldots \ldots \ldots \ldots(28)
\end{aligned}
$$

・ $\xi=0$ での位置ポテンシャル $\rho_{0} g H \eta / \pi$ :

この項は簡単に次のように書ける.

$\rho_{0} g H \eta / \pi$

- $\xi=-\infty$ での静圧項 $p_{-\infty}$ :

$\xi=-\infty$ での静圧項 $p-\infty$ 注, $\xi=0$ で $\eta$ を通る流線 の $\xi=-\infty$ での鉛直位置を $\eta^{\prime}$ として次のように書け る.

$$
p-\infty=p_{\infty}+\rho_{0} g \frac{H}{\pi} \int_{\eta^{\prime}}^{\pi}(\pi-\beta \eta) d \eta
$$

ここで, $\eta^{\prime}$ は $\xi=-\infty$ では流関数 $\Psi_{\boldsymbol{u}}$ と一致するから，

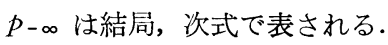

$$
\begin{aligned}
p_{-\infty}= & p_{\infty}+\rho_{0}\left[g \frac{H}{\pi} \sum_{n=1}^{\infty}\left(a_{n}+\delta A_{n}+\delta^{2} C_{n}\right) \sin n \eta\right. \\
& +g \frac{H}{\pi}(\pi-\eta)-\frac{1}{2} g \frac{H}{\pi} \beta\left(\pi^{2}-\eta^{2}\right) \\
& -g \frac{H}{\pi} \beta \eta \sum_{n=1}^{\infty}\left(a_{n}+\delta A_{n}+\delta^{2} C_{n}\right) \sin n \eta \\
& \left.+\frac{1}{2} g \frac{H}{\pi} \beta\left\{\sum_{n=1}^{\infty}\left(a_{n}+\delta A_{n}+\delta^{2} C_{n}\right) \sin n \eta\right\}^{2}\right]
\end{aligned}
$$

$$
\text { - } \xi=-\infty \text { での慣性項 : }
$$

$\xi=-\infty$ では流速は一定で $U_{\infty}$ に等しいので, この項 は近似的に次のように書ける.

$$
\left(\rho q^{2} / 2\right)_{\xi=-\infty} \fallingdotseq \rho_{0} U_{\infty}{ }^{2} / 2 \text {. }
$$

- $\xi=-\infty$ での位置ポテンシャル :

$\xi=-\infty$ での位置ポテンシャルは， $\xi=0$ で $\eta$ を通る 流線の $\xi=-\infty$ での高さを $\eta^{\prime}$ とすると, $\eta^{\prime}$ は流関数 に等しいから結局,

$$
-g \frac{H}{\pi} \Psi=g \frac{H}{\pi}\left\{\eta-\sum_{n=1}^{\infty}\left(a_{n}+\delta A_{n}+\delta^{2} C_{n}\right) \sin n \eta\right\}
$$

\section{と書ける.}

式 (27) 〜 (32) を用い， $\xi=0^{-}$と $\xi=-\infty$ でのトータ ル・エネルギーを等しくおき， $\delta$ のオーダーごとに整理 することにより， $A_{n}$ と $C_{n}$ に関する次の 2 式を得る.

$$
\begin{aligned}
& \delta^{(1)}: F \sum_{n=1}^{\infty} n A_{n} \cos n \eta=-\eta \sum_{n=1}^{\infty} a_{n} \sin n \eta \\
&+ \frac{1}{2}\left\{\sum_{n=1}^{\infty} a_{n} \sin n \eta\right\}^{2}-\sum_{n=1}^{\infty} \frac{a_{n}}{n}\left\{(-1)^{n}-\cos n \eta\right\} \\
& \ldots \ldots \ldots \ldots \ldots \ldots \ldots \ldots \ldots \ldots \ldots \ldots \ldots \ldots \ldots \ldots \ldots \ldots \ldots \ldots \ldots \ldots \ldots \ldots \ldots \\
& \delta^{(2)}: F \sum_{n=1}^{\infty} n C_{n} \cos n \eta=\sum_{n=1}^{\infty} \frac{A_{n}}{n}\left\{(-1)^{n}-\cos n \eta\right\} \\
&-\eta \sum_{n=1}^{\infty} A_{n} \sin n \eta+\frac{1}{2}\left\{\sum_{n=1}^{\infty} a_{n} \sin n \eta\right\}
\end{aligned}
$$




$$
\cdot\left\{\sum_{n=1}^{\infty} A_{n} \sin n \eta\right\}-\left\{\sum_{n=1}^{\infty}\left(n A_{n}+B_{n}\right) \sin n \eta\right\}^{2}
$$

ここで，F は一様流方向の流速成分,

$$
F=2\left\{-1+\sum_{n=1}^{\infty} n a_{n} \cos n \eta\right\}
$$

であり, 一定值とみなせる.

式(33), (34)より $A_{n}, C_{n}$ は次のように定まる.つま り, $A_{n}$ は以下の $A_{n, 1} \sim A_{n, 4}$ の和となる.

$$
\begin{aligned}
& A_{n, 1}=\frac{2 b \pi}{F(\pi-b \pi)^{m}(m+1)}\left[\frac{1}{n}\left\{b \pi \cos n \eta-(-1)^{n}\right\}\right. \\
& \left.-\frac{\sin n \pi b}{n^{2}}\right]+\frac{2 b \pi}{F(\pi-b \pi)^{m}(m+1)} \sum_{l=1}^{m+1}(-1)^{l} \\
& \cdot \frac{(m+1) !}{l !(m+1-l) !}\left[\frac{1}{n}\left\{(b \pi)^{l+1} \cos n \pi b-(-1)^{n}\right\}\right. \\
& -\frac{(l+1)}{n^{2}}(b \pi)^{l} \sin n \pi b-\frac{l(l+1)}{n^{3}} \\
& \cdot\left\{(b \pi)^{l-1} \cos n \pi b-(-1)^{n}\right\} \\
& +\frac{(l+1) !}{n^{4}(l-2) !}(b \pi)^{l-2} \sin n \pi b+\frac{(l+1) !}{n^{5}(l-3) !} \\
& \left.\left\{(b \pi)^{l-3} \cos n \pi b-(-1)^{n}\right\}+\cdots\right] \\
& A_{n, 2}=\frac{2}{F} \frac{b \pi}{(m+1)(m+2)(\pi-b \pi)^{m}} \\
& \cdot\left[\operatorname { c o s } n \pi b \left\{\frac{(\pi-b \pi)^{m+2}}{n}-\frac{(m+2) !(\pi-b \pi)^{m}}{n^{3}(m !)}\right.\right. \\
& \left.-\frac{(m+2) !(\pi-b \pi)^{m-2}}{n^{5}(m-2) !}+\cdots\right\} \\
& +\sin n \pi b\left\{\frac{(m+2) !(\pi-b \pi)^{m+1}}{n^{2}(m+1) !}\right. \\
& \left.\left.+\frac{(m+2) !(\pi-b \pi)^{m-1}}{n^{4}(m-1) !}+\cdots\right\}\right] \\
& A_{n, 3}=\frac{2 g_{1}}{F n}\left\{b \pi \cos n \pi b-(-1)^{n}-\frac{\sin n \pi b}{n}\right\}
\end{aligned}
$$

$$
A_{n, 4}=-\frac{2 g_{1}}{F n}\left\{(-1)^{n}-\cos n \pi b\right\}
$$

すなわち，

$$
A_{n}=\sum_{j=1}^{4} A_{n, j}
$$

で与えられる. なお， $g_{1}$ は $\psi_{1}$ の $\delta=0, \eta=\pi$ での条件 から定まる定数である.

$C_{n}$ も同様にして式 (34) の右辺の積分をフーリエ変換 することにより得られる. $C_{n}$ は $C_{n, 1} \sim C_{n, 7}$ の和で表 される。

$$
\begin{aligned}
C_{n, 1}= & \frac{2 b \pi(m !)}{F^{2}(m+2)(\pi-b \pi)^{m}} \\
& \cdot\left[\frac{1}{n}\left\{(b \pi)^{2} \cos n \pi b-(-1)^{n}\right\}-\frac{2}{n^{2}} b \pi \sin n \pi b\right. \\
& +\frac{2}{n^{3}}\left\{(-1)^{n}-\cos n \pi b\right\}
\end{aligned}
$$

$+\sum_{l=1}^{m+2}(-1)^{l} \frac{(m+2) !}{(l !)(m+2-l) !}$

$\cdot\left\{\frac{1}{n}\left((b \pi)^{l+2} \cos n \pi b-(-1)^{n}\right)\right.$

$-\frac{(l+2)}{n^{2}}(b \pi)^{l+1} \sin n \pi b-\frac{(l+1)(l+2)}{n^{3}}$

$\cdot\left((b \pi)^{l} \cos n \pi b-(-1)^{n}\right)$

$+\frac{(l+2) !}{n^{4}(l-1) !}(b \pi)^{l-1} \sin n \pi b$

$+\frac{(l+2) !}{n^{5}(l-2) !}\left((b \pi)^{l-2} \cos n \pi b-(-1)^{n}\right)$

$\left.\left.-\frac{(l+2) !}{n^{6}(l-3) !}(b \pi)^{l-3} \sin n \pi b+\cdots\right\}\right] \cdots$

$$
C_{n, 2}=\frac{6 b \pi(m !)}{F^{2}(\pi-b \pi)^{m}(m+3) !}
$$

$\cdot\left[\left\{\frac{1}{n}\left(b \pi \cos n \pi b-(-1)^{n}\right)-\frac{\sin n \pi b}{n^{2}}\right\}\right.$

$+\sum_{l=1}^{m+3}(-1)^{l} \frac{(m+3) !}{(l !)(m+3-l) !}$

$\cdot\left\{\frac{1}{n}\left((b \pi)^{l+1} \cos n \pi b-(-1)^{n}\right)\right.$

$-\frac{(l+1)(b \pi)^{l}}{n^{2}} \cos n \pi b-\frac{l(l+1)}{n^{3}}$

$\cdot\left((b \pi)^{l-1} \cos n \pi b-(-1)^{n}\right)$

$\left.\left.+\frac{(l+1) !}{n^{4}(l+2) !}(b \pi)^{l-2} \sin n \pi b+\cdots\right\}\right]$

$$
C_{n, 3}=\frac{4 b \pi(m !)}{F^{2}(m+4) !(\pi-b \pi)^{m}}
$$

$\cdot\left[\cos n \pi b\left\{\frac{(\pi-b \pi)^{m+4}}{n}-\frac{(m+4) !(\pi-b \pi)^{m+2}}{n^{3}(m+2) !}\right.\right.$

$\left.-\frac{(m+4) !(\pi-b \pi)^{m}}{n^{5}(m) !}+\cdots\right\}$

$+\sin n \pi b\left\{\frac{(m+4) !(\pi-b \pi)^{m+3}}{n^{3}(m+3) !}\right.$

$+\frac{(m+4) !(\pi-b \pi)^{m+1}}{n^{4}(m+1) !}$

$\left.\left.+\frac{(m+4) !(\pi-b \pi)^{m-1}}{n^{6}(m-1) !}\right\}\right]$

$C_{n, 4}=\frac{2 g_{2}}{3 F^{2}}\left[\frac{1}{n}\left\{(-1)^{n}-(b \pi)^{3} \cos n \pi b\right\}\right.$

$+\frac{3(b \pi)^{2}}{n^{2}} \sin n \pi b$

$\left.-\frac{6}{n^{3}}\left\{(-1)^{n}-b \pi \cos n \pi b\right\}-\frac{6}{n^{4}} \sin n \pi b\right]$

$C_{n, 5}=\frac{g_{2}}{F^{2}}\left[\frac{1}{n}\left\{(-1)^{n}-(b \pi)^{2} \cos n \pi b\right\}\right.$

$\left.+\frac{2 b \pi}{n^{2}} \sin n \pi b-\frac{1}{n^{3}}\left\{(-1)^{n}-\cos n \pi b\right\}\right]$

$C_{n, 6}=\frac{g_{4}}{2 n F}\left\{b \pi \cos n \pi b-(-1)^{n}-\frac{1}{n} \sin n \pi b\right\}$ 


$$
C_{n, 7}=\frac{2 g_{5}}{n F}\left\{\cos n \pi b-(-1)^{n}\right\}
$$

定数 $g_{2} \sim g_{5}$ は $\psi_{1}$ および $\psi_{2}$ の $\delta=0, \eta=\pi$ での境界 条件から定まるものであり，次式で与えられる．

$$
\begin{aligned}
& g_{2}=\frac{(b \pi)^{2}}{2 m+1}-\frac{(m !) b \pi(\pi-b \pi)}{(m+2) !} \\
& g_{3}=-g_{2} \\
& g_{4}=\frac{1}{F}\left[-\frac{(m !)(b \pi)^{2}(\pi-b \pi)^{2}}{(m+3) !}-\frac{3(m !) b \pi(\pi-b \pi)^{3}}{(m+4) !}\right. \\
& -\frac{g_{3}}{2}\left(\frac{2 \pi}{3}-b \pi+\frac{(b \pi)^{3}}{3}-g_{3}\left(\frac{\pi}{2}-b \pi-\frac{(b \pi)^{2}}{2}\right)\right]
\end{aligned}
$$

$g_{5}=-g_{4}$

\section{(2) $\boldsymbol{F}_{r_{\pi}}<1$ の場合の解}

a) 上流側の解 $\Psi_{\boldsymbol{a}}$

日野・大西 ${ }^{5), 6)}$ に従い, 座標変換,

$$
\xi^{\prime}=\frac{\xi}{\varepsilon}, \quad \eta^{\prime}=\frac{\eta}{\varepsilon}
$$

を導入し (ここで, $\left.\varepsilon=F_{r \pi}{ }^{2}\right)$ さらに解を $\varepsilon$ につての 摂動解で表す.

$$
\Psi_{u}=-\varepsilon \eta^{\prime}+\psi_{0}{ }^{\prime}+\varepsilon \psi_{1}{ }^{\prime}+\varepsilon^{2} \psi_{2}{ }^{\prime}+\cdots
$$

式（52）を基本式 (7) に代入し， $\varepsilon$ のオーダーごとに整 理し, さらに, 座標の逆変換を行ってもとにもどすと次 の方程式群を得る.

$$
\begin{aligned}
& \frac{\partial^{2} \psi_{0}{ }^{\prime}}{\partial \xi^{2}}+\frac{\partial^{2} \psi_{0}{ }^{\prime}}{\partial \eta^{2}}=0 \\
& \frac{\partial^{2} \psi_{m}{ }^{\prime}}{\partial \xi^{2}}+\frac{\partial^{2} \psi_{m}{ }^{\prime}}{\partial \eta^{2}}=-\frac{1}{\varepsilon^{2}} \psi_{m-1}{ }^{\prime}, \quad m \geq 1
\end{aligned}
$$

式 (53・a) より $\psi_{0}^{\prime}$ の解は $F_{r \pi}>1$ の場合とまったく 同様に求められる。また， $m \geq 1$ の解も， $F_{r \pi}>1$ の 場合の解に $1 / \varepsilon^{2}$ を乗ずればよい. したがって， $F_{r \pi}$ の 2 つの範囲における解は $F_{r \pi}>1$ の解 $\psi_{i}$ により次式 のように書ける.

$$
\Psi_{u}{ }^{\prime}=-\eta+\psi_{0}+\mu_{1} \psi_{1}+\mu_{2} \psi_{2}+\cdots
$$

係数 $\mu_{1}, \mu_{2}, \cdots$ は $F_{r \pi}$ の值により次のように書ける.

$$
\begin{aligned}
& \mu_{1}= \begin{cases}F_{r^{2}}{ }^{-2}, & F_{r_{\pi}}>1 \\
F_{r_{\pi}}{ }^{-2}, & F_{r_{\pi}}<1\end{cases} \\
& \mu_{2}= \begin{cases}F_{r_{\pi}}{ }^{-4}, & F_{r_{\pi}}>1 \\
F_{r^{0}}{ }^{0}, & F_{r_{\pi}}<1\end{cases}
\end{aligned}
$$

b) 下流側の解 $\Psi_{d}{ }^{\prime}$

Barrier 下流側の解 $\Psi_{d}{ }^{\prime}$ \& $F_{r \pi}>1$ の場合とまった く同様に求めることができる，つまり， $\Psi_{d}{ }^{\prime}$ は,

$$
\begin{aligned}
\Psi_{d}{ }^{\prime}= & -\eta+\sum_{n=1}^{K}\left\{G_{n}{ }^{\prime} \sin \lambda_{n} \xi+H_{n}{ }^{\prime} \cos \lambda_{n} \xi\right\} \sin n \eta \\
& +\sum_{n=K+1}^{\infty}\left\{J_{n}^{\prime} e^{-\lambda_{n} \xi}+K_{n}{ }^{\prime}\right\} \sin n \eta \cdots \cdots(55)
\end{aligned}
$$

で表され, 係数 $G_{n}{ }^{\prime}, H_{n}{ }^{\prime}, J_{n}{ }^{\prime}, K_{n}{ }^{\prime}$ は $F_{r \pi}>1$ の場 合上形式的に问样に等まる。
$F_{r \pi}<1$ についての第 2 次攝動解 $\psi_{1}{ }^{\prime}$, 第 3 次搨動解 $\psi_{2}^{\prime}$ の係数 $A_{n}{ }^{\prime}, C_{n}{ }^{\prime}$ (式 (15)の $A_{n}$ および式 (17) の $C_{n}$ に相当する) \& $F_{r \pi}>1$ の場合と同様に求められ る. その結果, $A_{n}{ }^{\prime}, C_{n}{ }^{\prime}$ は次のように書ける.

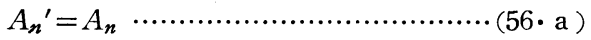

$$
\begin{aligned}
& C_{n}{ }^{\prime}=0
\end{aligned}
$$

\section{4. 理論モデルの結果}

\section{（1） Barrier 高さの違いによる流れの変化}

3. で述べた理論モデルで計算した鉛直 Barrier のま わりの流線を描いたものが 図一3〜5 である. 図一3 は $b=0.15$ の Barrier で $F_{r \pi}=0.58$ に拈りる流線を示 す.また，図-4, 5 は，それぞれ $b=0.2$ の Barrier に ついて $F_{r_{\pi}}=3.16$, および 0.58 での流線を示したもの である. $F_{r \pi}$ が小さくなり浮力の効果が強くなると, 流 れに波動が表れ，Barrier が大きい場合には上流側に渦 流域が形成される.この渦流域は $\mathrm{Kao}^{3)}$ のモデルでは 静水域とされ, Barrier 高さとは無関係に $F_{r \pi}=1$ で生 ずると考えられている. しかしながら，このモデル結果 に示されるように Barrier が大きいほど, 大きなフルー ド数でも渦流城が形成される. 以下の議論では, この渦 流域を “よどみ域”とよぶこととする.

図一6 は, 同じフルード数での Barrier 上流側の流速 分布を異なる高さの Barrier について比較したものであ る. 流速分布は，すべて Barrier 高さと等しい距離だけ 上流側の点でのものである. Barrier 高さによって流速 分布が大きく異なり, 高い Barrier について渦流域が形 成されやすいことが知られる.よどみ域の形成される最 大のフルード数 $F_{r \pi}$ (これを以降で臨界フルード数 $F_{r \pi c}$ とよぶ）は，大気中での山越え気流に関連して Sheppard ${ }^{7)}$ により論じられた．彼は気塊が山を越えるに 必要な最小限の風速は山の高さに無関係ではないと考え 慣性力と浮力のつり合いから最低風速を推定している. 彼の結果汢山が高くなるほど, 最低風速が大となる.つ まり， $F_{r \pi c}$ が大となることを示した．筆者の理論モデ ルの結果は Sheppard の推論と合致している.

Barrier 下流側の流れもフルード数の減少とともに変 化する. つまり, 密度成層効果が弱い（ $\mathrm{F}_{r \pi}$ が大きい） 場合に下流側に遠くまで達していた後流 Wake は，フ ルード数の減少とともに縮退し, 渦流域内の渦度も弱く なることが知られる.これについては (4) で述べる.

\section{（2）よどみ域範囲とフルード数の関係}

上流側上どみ域の空間的な範囲は流関数が正の領域で 表される。したがって，上どみ域の上部の境界は上えら 


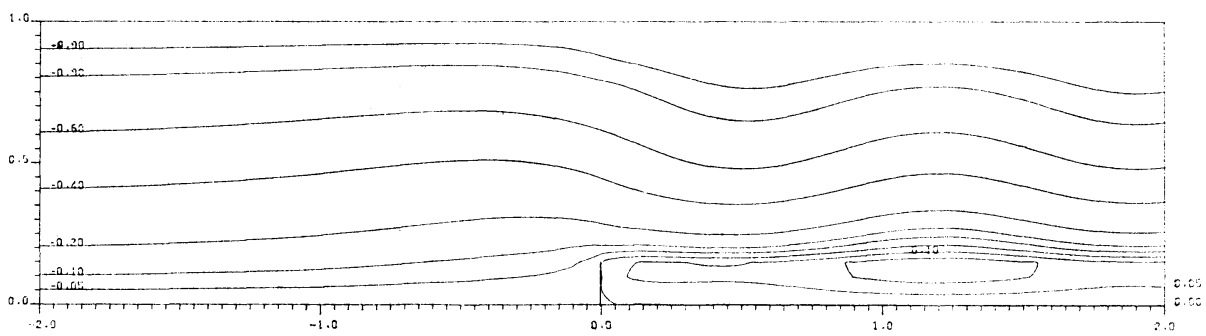

図一3 Barrier のまわりの流線 $\left(b=0.15, F_{r_{\pi}}=0.58\right)$

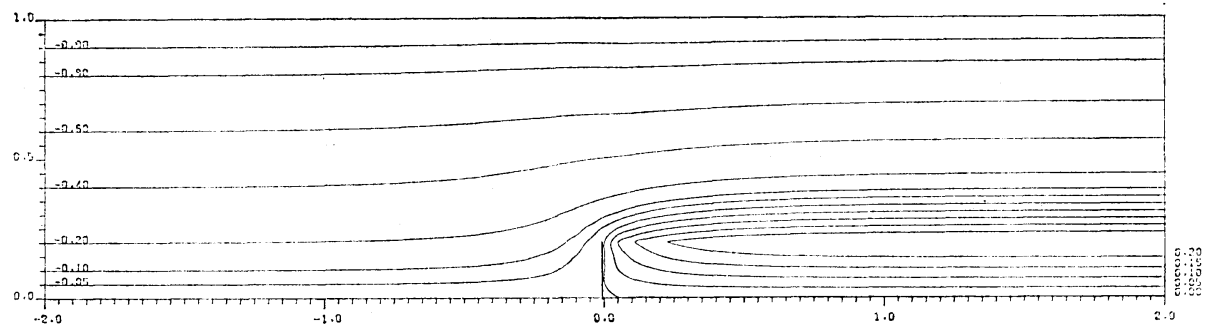

図-4 Barrier のまわりの流線 $\left(b=0.2, F_{r_{\pi}}=3.16\right)$

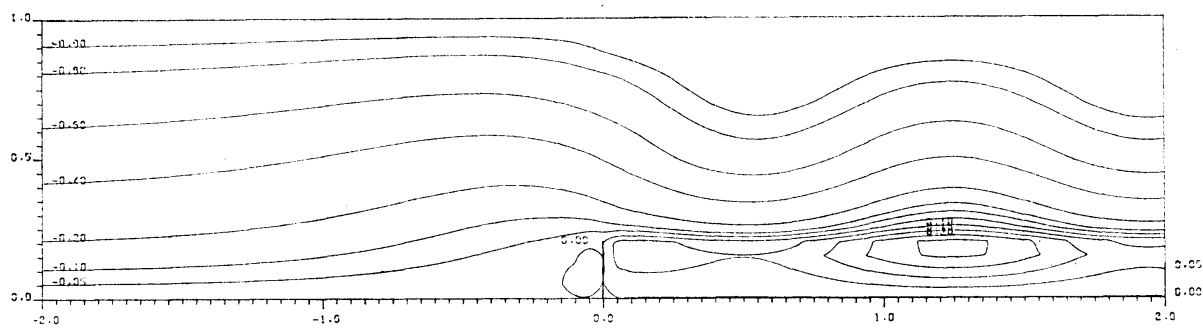

図一5 Barrier のまわりの流線 $\left(b=0.2, F_{r_{\pi}}=0.58\right)$

れた $\xi$ について $\Psi$ が 0 となる $\eta$ で定まる.つまり， 式(54)で与えられた $\xi$ について， $\Psi$ が 0 となる $\eta\left(=\eta_{s}\right)$ を求めれば, それがよどみ域の上縁を与える.

$n$ について 1 から 3 までの項を考え, Barrier 高さがチ ヤンネルの深さに比較して十分小さいとすれば, $\sin n \eta$ について次の近似が可能である.

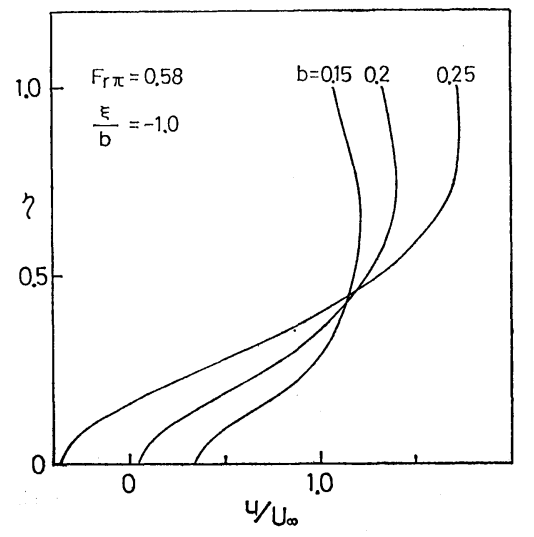

图一6 Barrier 上流側流速分布の Barrier 高さによる 相違 $\left(F_{r_{\pi}}=0.58, \xi / b=-1.0\right.$ の点での分布を示 す) $\sin \eta \doteqdot \eta$

(57. a )

$\sin 2 \eta \doteqdot 2 \eta\left(1-\eta^{2} / 2\right)$

$\sin 3 \eta \doteqdot 3 \eta-4 \eta^{3}$

式 $(57 \cdot a) 〜(57 \cdot c)$ を用いることにより式(54) は次のよ うに書き換えられる.

$$
f_{1} \eta+f_{2}\left(2 \eta-\eta^{3}\right)+f_{3}\left(3 \eta-4 \eta^{3}\right)-\eta=0 \cdots
$$
ここで,

$$
\begin{aligned}
f_{n}= & \left\{a_{n}+\mu_{1}\left(A_{n}+B_{n} \xi\right)+\mu_{2}\left(C_{n}+D_{n} \xi\right.\right. \\
& \left.\left.+E_{n} \xi^{2}\right)\right\} e^{n \xi} \ldots \ldots \ldots \ldots \ldots \ldots \ldots \ldots \ldots \ldots \ldots \ldots \ldots \ldots \ldots
\end{aligned}
$$

であり，よどみ域の上縁 $\eta_{s}$ は次のように定まる.

$$
\eta_{s}=\left\{\frac{f_{1}+2 f_{2}+3 f_{3}-1}{f_{2}+4 f_{3}}\right\}^{1 / 2}
$$

式(60)より求めたよどみ域の範囲とフルード数の関係 を図一7, 8 に示す. 図一7 は $b=0.2$, 図一8 は $b=0.25$ に対応している.フルード数の減少とともによどみ域は 急速に発達することが知られよう.

\section{（3）よどみ域発生の臨界フルード数}

（2）で述べたように，よどみ域の上縁は $\xi$ と $F_{r \pi}$ の 関数として式 (60) で与えられる. 式中の分子項は $F_{r \pi}$ が大きい場合には, $\left(f_{1}+2 f_{2}+3 f_{3}\right)$ の項が小さいた め, 全体として負の值をとる.つまり, この場合には 


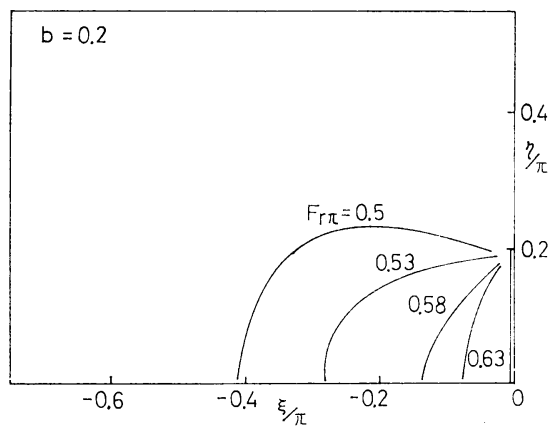

図一7 Barrier 上流側よどみ域のフルード数による 変化 $(b=0.2)$

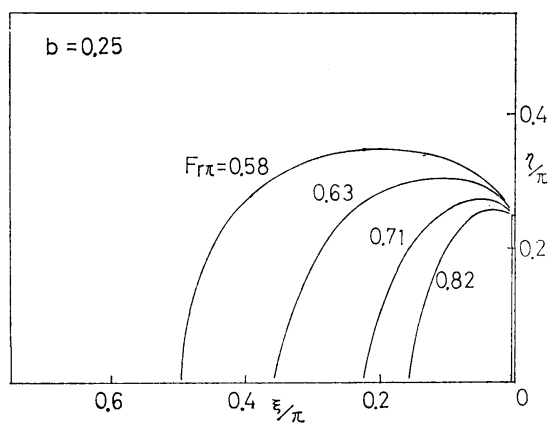

図一8 Barrier 上流側よどみ域のフルード数による 変化 $(b=0.25)$

$\eta_{s}$ が実の值をもたず，よどみ域が 形成されていないこ とを示している. 密度成層効果が相対的に大になるに従 い $\mu_{i}$ が大となり, 分子項が 0 に近ゔく. 分子項が正と なったところで初めて $\eta_{s}$ が実の值をもち，よどみ域が 形成されることを示す. つまり, よどみ域の発生臨界フ ルード数 $F_{r \pi c}$ は式 (60) の分子項が 0 となる $F_{r \pi}$ に対 応する.

$F_{r \pi c}$ は, それ自身と 1 との大小関係に応じ次の 2 式 のうちのどちらかで定まる.

$F_{r \pi c}>1$ の場合

$$
F_{r \pi c}{ }^{-2}=\frac{-F_{2}+\sqrt{F_{2}^{2}-4 F_{1} F_{3}}}{2 F_{1}}
$$

$F_{r \pi c}<1$ の場合

$$
F_{r \pi c}{ }^{-2}=\frac{1-\left(F_{1}+F_{3}\right)}{F_{2}}
$$

ここで, $F_{i}$ は次式で与えられる.

$$
\begin{aligned}
& F_{1}=\sum_{n=1}^{3} n\left(C_{n}+D_{n} \xi+E_{n} \xi^{2}\right) e^{n \xi} \\
& F_{2}=\sum_{n=1}^{3} n\left(A_{n}+B_{n} \xi\right) e^{n \xi} \ldots \ldots \ldots \\
& F_{3}=\sum_{n=1}^{3} n a_{n} e^{n \xi}-1 \ldots \ldots \ldots \ldots \ldots \ldots \ldots \ldots
\end{aligned}
$$

\section{(4) Barrier 下流側の Wake}

前に述べたように, 下流側の Wake 領域は非成層条

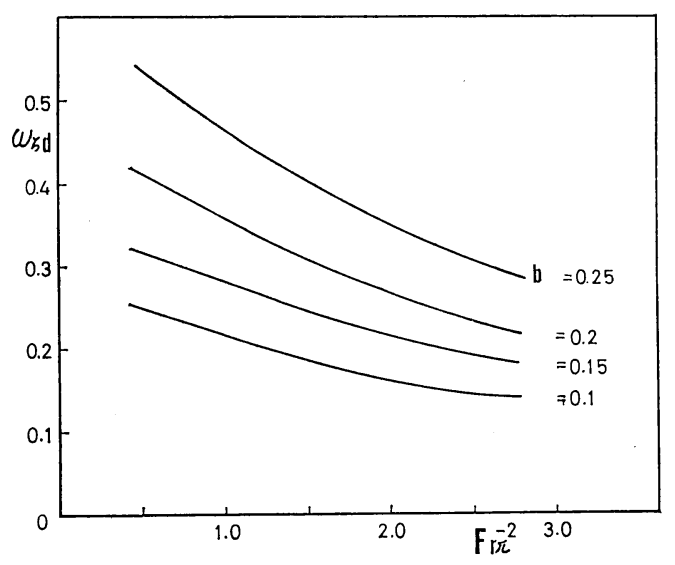

図一9 Barrier 下流側の Wake の渦度の密度成層 パラメーター $\boldsymbol{F}_{r_{\pi}}{ }^{-2}$ による変化

件 $\left(F_{r \pi}=\infty\right)$ では風下無限遠にまで及んでいる，密度 成層効果が増加すると, この Wake 領域は小さく, ま た, 内部の渦度も減少する. 図一9 は Wake の強さを 表す Wake 内の渦度が成層パラメーター $F_{r \pi}{ }^{-2}$ により どのように変化するかを示したものである. 図で明らか なように, 成層効果が大となる.つまり, $F_{r \pi}{ }^{-2}$ が増加 すると渦度 $\omega_{\zeta d}$ は減少する. また, 流線図（図一4, 5）からも明らかなように, Barrier 直下流の Wake 域 も縮少してゆく.このように, 密度成層効果の増大に伴 い, Barrier 下流側の Wake はその強さ, スケールと ともに減少してゆくことが示された.

\section{5. 風洞実験}

理論モデルにより示されたよどみ域の形成, およびそ の臨界フルード数と Barrier 高さの関係を確かめるため 風洞による流れの観察を行った.

\section{（1）実験装置と測定方法}

実験は公害資源研究所の小型風洞（図一10）により行 った. 風洞は押し込み式であり，3 相超分巻電動機 ( 3 相 $200 \mathrm{~V}, 11 \mathrm{~kW})$ と直径 $800 \mathrm{~mm}$ の軸流送風機の組み 合わせにより, 測定部で約 $0.2 \sim 20 \mathrm{~m} / \mathrm{s}$ の風速が得られ る. 測定部は断面 $0.6 \times 0.6 \mathrm{~m}$, 長さ $5 \mathrm{~m}$ であり, 側面 は片側のみガラス空となっている.

風洞内の密度分布（温度分布）は測定部上流端に取り 付けた気流加熱装置により, 高さ方向に温度勾配を与え ることにより作られる. 気流加熱装置は高さ方向に $4 \mathrm{~cm}$ 間隔で取り付けた厚さ $0.3 \mathrm{~cm}$, 流れ方向の幅 $12 \mathrm{~cm}$ の 13 枚のプレートヒータとその制御部で構成される.プレ ートヒータへの供給電流を各ヒータ・エレメントごとに 変えることにより, 高さ方向に温度分布がつけられる.

Barrier の前後での流速分布測定にはスモークワイヤ 


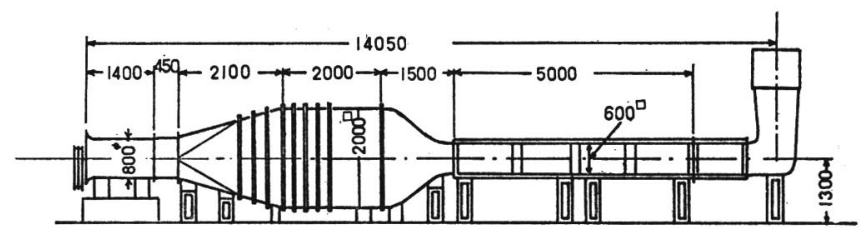

図一10 小型風洞の外観 図

装置が用いられた. スモーク・ワイヤ法は可視化測定法 であるため低流速でも測定可能であるほか，気流温度な どにもあまり影響されないため, 密度成層流の測定に適 している. 発煙部は直径 50 ミクロン, 長さ $30 \mathrm{~cm}$ の夕 ングステン線である.

風洞によるよどみ流の測定は 3 種類の高さの Barrier について行われた. Barrier の高さは $5,11,15 \mathrm{~cm}$ であ り風洞測定部高さで無次元化した高さb はそれぞれ， $0.08,0.18,0.25$ である.

Barrier は風洞測定部入口より, $3.5 \mathrm{~m}$ 風下に置かれ た. また, 実験時の風速は $0.15 \sim 0.4 \mathrm{~m} / \mathrm{s}$ であり, 境界 層の厚さは $2 \mathrm{~cm}$ 程度と思われる。

\section{（2）流速分布および密度分布}

スモークワイヤにより Barrier 上流側で得られた線条 煙の写真を図一11, 12 に示す. 図一11 は高さ $15 \mathrm{~cm}$, つまり, $b=0.25$ の Barrier の $60 \mathrm{~cm}$ 上流側で $F_{r \pi}=$ 0.71 の条件で得られた 線条煙写真である. 下層では線 条煙がほとんど移動しておらず, 流れが停滞しているこ とが知られる. しかしながら, 滞留域,つまり, よどみ 域はあまり厚くはない，図一12 は同じ Barrier につい て, 同じ位置で, $F_{r \pi}=0.58$ において得られた線条煙で

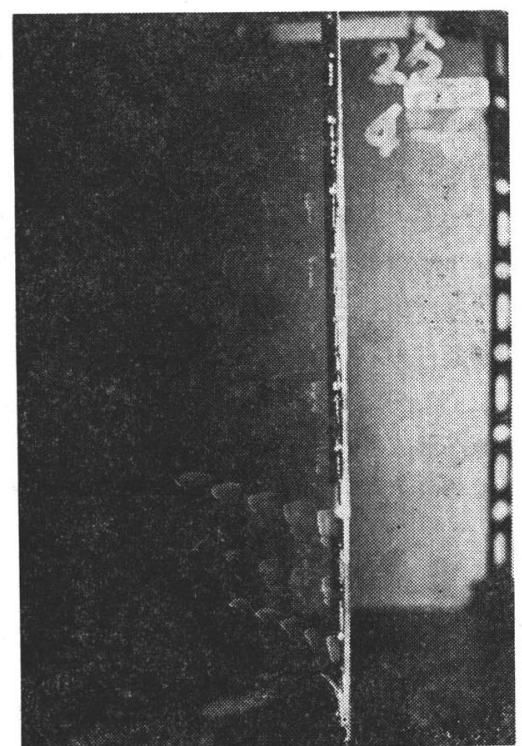

図一11 Barrier 上流側でのスモークワィヤ写真 $(b=0.25$, $F_{r_{\pi}}=0.71, X=-60 \mathrm{~cm}$. 流れは右から左へ)
ある.この場合には滞留層はかなり厚く, よどみ域が発達したことを示している.こ れらの風洞実験結果から得た流速分布, 密 度分布（実際注温度分布）を理論モデル結 果と比較したものが 図一13〜15 である. 流速分布については, 理論モデルでは粘性 を無視しているため，境界層の影響する下 層では実験結果と若干異なる。しかしながら，全体的な 両者の一致はおおむね良好である. $F_{r \pi}=0.58$ では, 理 論モデル, 実験結果とも, かなり上流側までよどみ域が 及んでいることを示している. 図一15 は， $b=0.25, F_{r \pi}$ $=0.58$ の条件での密度分布（実験では温度差の分布）を 理論モデルの結果と比較したものである. 両者の一致が きわめてよいことがわかる，なお，図で $\Delta T_{0}$ は床面と

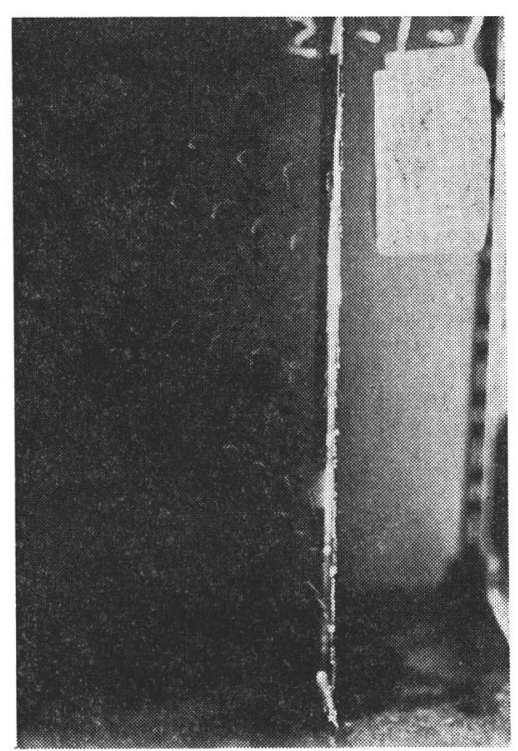

図-12 Barrier上流側でのスモークワイヤ写真 $(b=0.25$, $F_{r_{\pi}}=0.58$, 下層の滞留層がかなり厚くなっている)

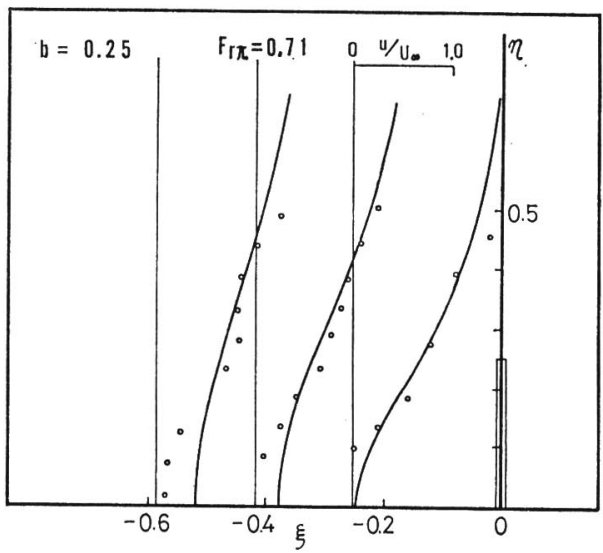

図一13 Barrier 上流側流速分布についての理論モデル （実線）と実験結果 $(O)$ の比較 $\left(b=0.25, F_{r_{\pi}}\right.$ $=0.71$ ) 


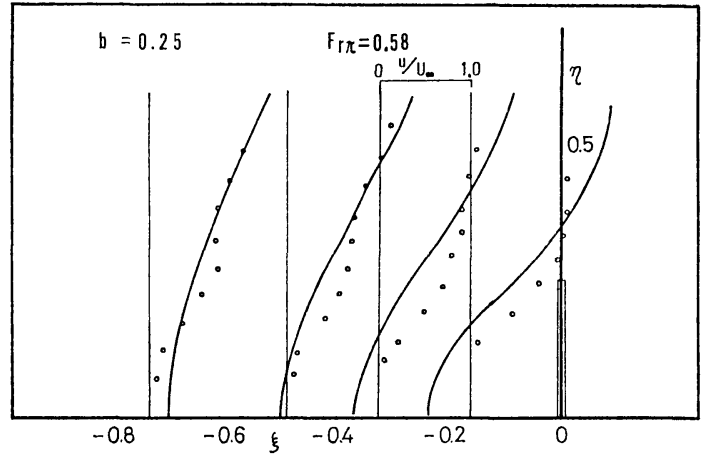

図一14図一13 に同じ（ただし， $b=0.25, F_{r_{\pi}}=0.58 ）$

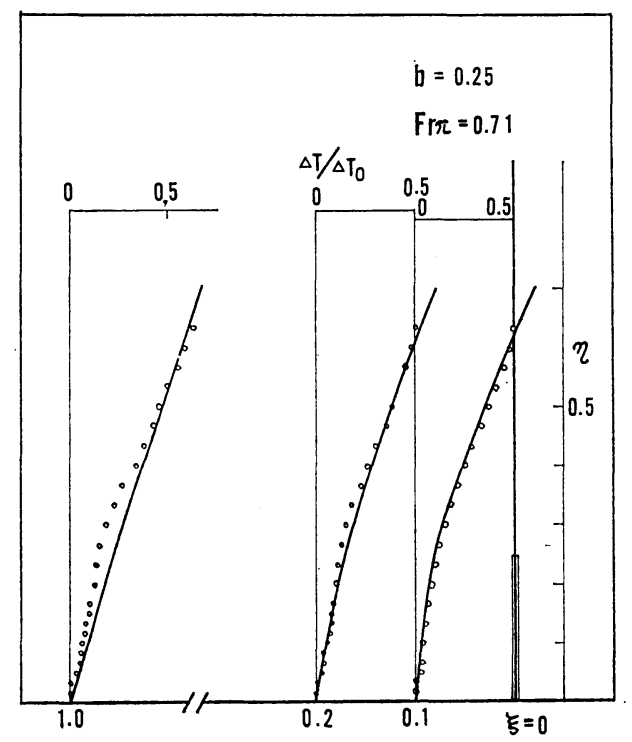

図一15 密度勾欺に対する理論モデル（実線）と実験（） の比較 $\left(b=0.25, F_{r_{\pi}}=0.71\right)$

天井面での気流温度差である.

\section{(3) フルード数臨界值 $\boldsymbol{F}_{r \pi c}$}

風洞実験結果からよどみ域の発生のみられた最大のフ ルード数 $F_{r \pi c}$ を求め, 理論モデルから推定された関倸 と同時に示したものが 図一16 である. 図では横軸に Barrier の高さ $b$ を綐軸に $F_{r \pi c}$ をとってある. 図で明 らかなように, よどみ域発生臨界フルード数 $F_{r \pi c}$ は, ほぼ Barrier の高さ $b$ に比例しており, 実駼結果とも おおむね一致している． $F_{r \pi}$ を $b$ で除した值，つまり， Barrier 高さを基準とするフルード数 $F_{r b}$ を次のように 定義する.

$$
F_{r b}=\frac{U \pi}{N b H}
$$

よどみ域の発生する $F_{r b}$ の臨界值 $F_{r b c}$ は, $0.8 \pi(b=$ $0.1) \sim 1.0 \pi(b=0.25)$ となり, ほぼ $\pi$ の程度である. なお, 接地逆転層時の山の前面でのよどみ域について

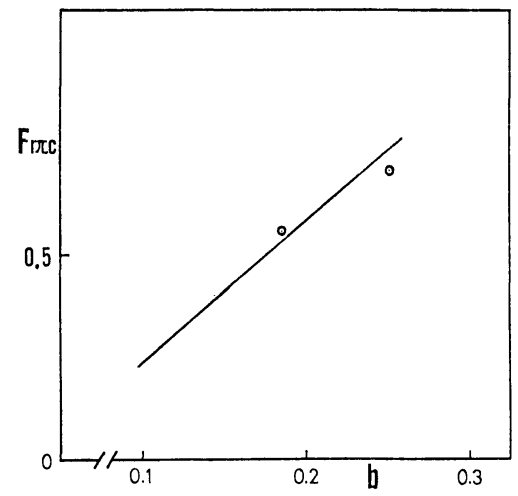

図一16 臨界フルード数 $\boldsymbol{F}_{r_{\pi} c}$ の理論モデル（実線）と 風洞実験結果 $(\odot)$

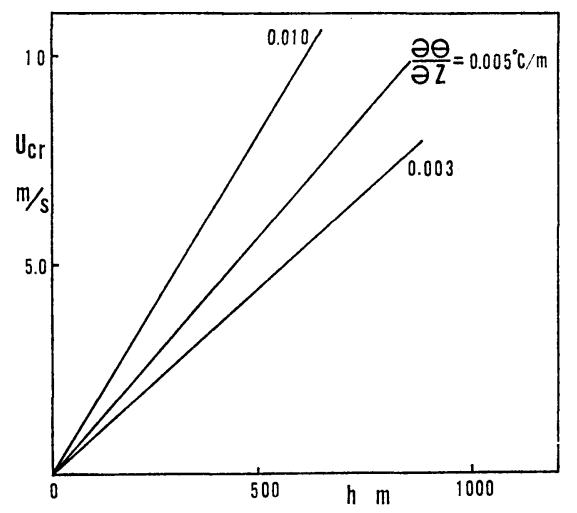

図一17 いくつかの温位勾配に対するよどみ域臨界風 速と山の高さの関係

は，Kitabayashi ${ }^{13)}$ により大気中での観測，および風洞 実験の両方から検討された. その場合の $F_{r b c}$ は，おお よそ $2.3 \pi$ であった.これは, 接地逆転層条件では密度 勾配が下層ほど強くなり, 本報告で扱った一様密度勾配 より浮力効果が強く働くためであろう.

以上で得られた $F_{r b c}$ の值を考慮して, 大気中で起こ り得るいくつかの密度成層条件について, 山の前面での よどみ域発生限界風速を示したものが 図一17 である. 大気中での密度勾配は温位勾配と等価であるため, 温位 勾配を成層条件のパラメーターとした. 高さ $500 \mathrm{~m}$ の山 岳では, 温位勾配が $0.01^{\circ} \mathrm{C} / \mathrm{m}$ のとき, 風速約 $8 \mathrm{~m} / \mathrm{s}$ で もよどみ城が形成される.この結果は Sheppard の簡単 な計算による值より若干小さいが，おおむね一致してい る.

\section{6. 結論}

安定成層大気条件において山の前面に発生するよどみ 域の性質を明らかにするため，流れを薄板 Barrier を越 える一様密度成層チャンネル流で近似し, 理論モデル, 
風洞実験により検討したままがきで述べたようによ どみ城内では流線が閉じ, 物質の滞留が生ずるため, 山 岳, 丘陵などの近くに污染質等を排出する施設等を設置 する場合には, 以下の諸点を十分吟味することが肝要で ある. 理論モデルおよび風洞実験で明らかとなった事柄 は以下の 4 点である.

（1）密度成層効果が強くなると Barrier 上流側に流 線の閉じたよどみ域が形成される.

（2）よどみ域はフルード数の減少とともに発達す る.

（3）よどみ域の発生を支配するパラメーターは，内 部フルード数 $F_{r \pi}$ であり， $F_{r \pi}$ がある臨界值 $F_{r \pi c}$ 以 下でよどみ域が形成される， $F_{r \pi c}$ は基準高さをチャン ネルの深さにとると, Barrier 高さに比例して増加する が, Barrier の高さを基準とすればほぼ一定值となる.

(4) Barrier 下流側の Wake 領域は, 浮力効果の 増加, つまり, フルード数の減少とともに縮少してゆ く.これと同時に Wake 内の渦度も減少する.

謝辞 : 本研究をとりまとめるにあたり, 有益なご 示唆, ご意見を下さった, 東京工業大学土木工学科 日野 幹雄教授, 同 吉川秀夫元教授に心から謝意を表します.

また, 研究の遂行にご理解, ご協力いただいた公害資 源研究所公害第一部第一課長 横山長之博士ならびに課 員の方々に感謝いたします.

\section{参 考 文 献}

1) Long, R.R. : Some Aspects of the Flow of Stratified
Fluids I, A Theoretical Investigation, Tellus, Vol. 5, p. $42,1953$.

2) Long, R.R. : Some Aspects of the Flow of Stratified Fluid II, Experiments with a Two-Fluid System. Tellus, Vol. 6, p. 97, 1954.

3) Kao, T.W.: The Phenomenon of Blocking in Stratified Fluid, Jour. of Geophy. Res., Vol. 70, p. 815, 1965.

4) Kao, T.W. : A Free Streamline Solution for Stratified Flow into a Line Sink, Jour. of Fluid Mech., Vol. 21, p. $535,1965$.

5）日野幹雄・大西外明 : 密度成層流におよぼす Point Sink の高さの効果, 土木学会諭文報告集, 第 163 号, p. 39, 1969.

6）日野幹雄・大西外明：円筒型取水塔のスリットへの密度 成層流, 土木学会論文報告集, 第 178 号, p. 37, 1970.

7) Sheppard, P.A. : Air Flow over Mountaines, Quart. Jour. of Roy. Met. Soc., Vol. 82, p. 528, 1956.

8) Yih, C.S. : On the Flow of a Stratified Fluid, Proc. of 3rd US National Congress of Appl. Mech., p. 857, 1958.

9) McIntyre, M.E. : On Long's Hypothesis of No Upstream Influence in Uniformly Stratified or Rotating Fluid, Jour. of Fluid Mech., Vol. 52, p. 209, 1972.

10) Baines, P.G. : Upstream Influence and Long's Model in Stratified Flows, Jour. of Fluid Mech., Vol. 82, p. $147,1977$.

11) Wei, S.N., T.W. Kao and H.P. Pao : Experimental Study of Upstream Influence in the Two-Dimensional Flow of a Stratified Fluid over an Obstacle, Geophy. Fluid Dynamics, Vol. 6, p. 315, 1975.

12) Trustrum, K. : Rotating and Stratified Fluid Flow, Jour. of Fluid Mech., Vol. 19, p. 415, 1964.

13) Kitabayashi, K. : Wind Tunnel and Field Studies of Stagnant Flow Upstream of a Ridge, Jour. of Met. Soc. Japan, Vol. 55, p. 193, 1977.

(1979.11.24 • 受付) 